\title{
High Level Aminoglycoside Resistance and Distribution of Aminoglycoside Resistant Genes among Clinical Isolates of Enterococcus Species in Chennai, India
}

\author{
Elango Padmasini, ${ }^{1}$ R. Padmaraj, ${ }^{2}$ and S. Srivani Ramesh ${ }^{1}$ \\ ${ }^{1}$ Department of Microbiology, Dr ALM Post Graduate Institute of Basic Medical Sciences, University of Madras, Chennai 600 113, India \\ ${ }^{2}$ Department of Paediatric Nephrology, Institute of Child Health and Research Centre, Chennai 600 008, India \\ Correspondence should be addressed to S. Srivani Ramesh; dr.srmicro@gmail.com
}

Received 27 August 2013; Accepted 26 November 2013; Published 4 February 2014

Academic Editors: J. P. Ackers and E. P. Sampaio

Copyright (c) 2014 Elango Padmasini et al. This is an open access article distributed under the Creative Commons Attribution License, which permits unrestricted use, distribution, and reproduction in any medium, provided the original work is properly cited.

\begin{abstract}
Enterococci are nosocomial pathogen with multiple-drug resistance by intrinsic and extrinsic mechanisms. Aminoglycosides along with cell wall inhibitors are given clinically for treating enterococcal infections. 178 enterococcal isolates were analyzed in this study. E. faecalis is identified to be the predominant Enterococcus species, along with E. faecium, E. avium, E. hirae, E. durans, E. dispar and E. gallinarum. High level aminoglycoside resistance (HLAR) by MIC for gentamicin (GM), streptomycin (SM) and both (GM + SM) antibiotics was found to be $42.7 \%, 29.8 \%$, and $21.9 \%$, respectively. Detection of aminoglycoside modifying enzyme encoding genes (AME) in enterococci was identified by multiplex PCR for $a a c\left(6^{\prime}\right)-I e-a p h\left(2^{\prime \prime}\right)-I a ; a p h\left(2^{\prime \prime}\right)-I b ; a p h\left(2^{\prime \prime}\right)-I c ; a p h\left(2^{\prime \prime}\right)-I d$ and $a p h\left(3^{\prime}\right)$ IIIa genes. $38.2 \%$ isolates carried $a a c\left(6^{\prime}\right)$-Ie-aph $\left(2^{\prime \prime}\right)$-Ia gene and $40.4 \%$ isolates carried $a p h\left(3^{\prime}\right)$-IIIa gene. $\operatorname{aph}\left(2^{\prime \prime}\right)-I b$; $a p h\left(2^{\prime \prime}\right)-I c$; $a p h\left(2^{\prime \prime}\right)$-Id were not detected among our study isolates. $a a c\left(6^{\prime}\right)$-Ie-aph $\left(2^{\prime \prime}\right)$-Ia and $a p h\left(3^{\prime}\right)$-IIIa genes were also observed in HLAR E. durans, E. avium, E. hirae, and E. gallinarum isolates. This indicates that high level aminoglycoside resistance genes are widely disseminated among isolates of enterococci from Chennai.
\end{abstract}

\section{Introduction}

Enterococci have emerged as an important multiple-drug resistant nosocomial pathogen reported worldwide. Its resistance to wider range of antimicrobial agents particularly, aminoglycosides, glycopeptides and beta-lactams had increasingly been documented [1]. Although enterococci are intrinsically resistant to low levels of aminoglycosides, high level resistance to aminoglycosides (MIC $\geq 2000 \mu \mathrm{g} / \mathrm{mL}$ ) is mediated by acquisition of genes encoding AMEs. High level gentamicin resistance (MIC $\geq 500 \mu \mathrm{g} / \mathrm{mL}$ ) in enterococci is predominantly mediated by $a a c\left(6^{\prime}\right)-I e-a p h\left(2^{\prime \prime}\right)-I a$, which encodes the bifunctional aminoglycoside modifying enzyme $\mathrm{AAC}\left(6^{\prime}\right)-\mathrm{APH}\left(2^{\prime \prime}\right)$. The action of this enzyme in enterococci eliminates the synergistic activity of gentamicin when combined with a cell wall active agent, such as ampicillin or vancomycin. Recently, newer AME genes such as aph $\left(2^{\prime \prime}\right)$ $I b$, aph $\left(2^{\prime \prime}\right)-I c$, and $a p h\left(2^{\prime \prime}\right)$-Id have been detected as those conferring gentamicin resistance in enterococci. High level streptomycin and kanamycin resistance in enterococci are mediated by aph $\left(3^{\prime}\right)$-IIIa gene encoding aminoglycoside phosphotransferase enzyme, APH $\left(3^{\prime}\right)$-IIIa [2]. In India, high level aminoglycoside resistance has been reported from different centers; however, studies on prevalence of these resistance genes are limited. The goal of this study is to determine, the rate of high level aminoglycoside resistance and aminoglycoside resistance encoding genes in enterococcal isolates collected from different specimen sources in Chennai, India.

\section{Materials and Methods}

2.1. Bacterial Strains. A total of 178 nonidentical clinical isolates of enterococci were obtained from clinical specimens from various tertiary care centers from Chennai, during a period of 2010-2012. Appropriate inpatient details were collected and recorded to avoid identical isolates from the 
TABLE 1: Primers and their sequences for aminoglycoside resistance encoding genes used in multiplex PCR.

\begin{tabular}{llll}
\hline Genes & \multicolumn{2}{c}{ Primer sequences $\left(5^{\prime}-3^{\prime}\right)$} & $\begin{array}{c}\text { Size of PCR } \\
\text { product }(\mathrm{bp})\end{array}$ \\
\hline$a a c\left(6^{\prime}\right)-I e-a p h\left(2^{\prime \prime}\right)-I a$ & F: CAGGAATTTATCGAAAATGGTAGAAAAG & R: CACAATCGACTAAAGAGTACCAATC \\
$a p h\left(2^{\prime \prime}\right)-I b$ & F: CTTGGACGCTGAGATATATGAGCAC & R: GTTTGTAGCAATTCAGAAACACCCTT & 867 \\
$a p h\left(2^{\prime \prime}\right)-I c$ & F: CCACAATGATAATGACTCAGTTCCC & R: CCACAGCTTCCGATAGCAAGAG & 444 \\
$a p h\left(2^{\prime \prime}\right)-I d$ & F: GTGGTTTTTACAGGAATGCCATC & R: CCCTCTTCATACCAATCCATATAACC & 641 \\
$a p h\left(3^{\prime}\right)-I I I a$ & F: GGCTAAAATGAGAATATCACCGG & R: CTTTAAAAAATCATACAGCTCGCG & 523 \\
\hline
\end{tabular}

same patient. An Institutional ethical clearance was obtained for conducting this study (reference number: 1168). The strains were initially grown on MacConkey agar (MV082) and Enterococcus confirmatory agar (M392) (HiMedia, Mumbai, India). Species characterization was carried out by carbohydrate fermentation test using $1 \%$ sugars such as sucrose, sorbose, sorbitol, mannitol, glucose, pyruvate, inulin, ribose, melibiose, raffinose, arabinose, and arginine. All the isolates were confirmed for genus and species by standard protocols [3]. Enterococcus faecium and Enterococcus faecalis were further confirmed by PCR analysis using specific $d d l_{\text {E.faecium }}$ and $d d l_{E \text {.faecalis }}$ genes, respectively [4].

2.2. Minimum Inhibitory Concentration for Aminoglycosides. The isolates were confirmed as high level aminoglycoside resistant enterococci (HLARE) by considering growth $\geq 512 \mu \mathrm{g} / \mathrm{mL}$ for gentamicin and $\geq 2048 \mu \mathrm{g} / \mathrm{mL}$ for streptomycin. The overnight bacterial cultures were adjusted to 0.5 McFarland's turbidity and the inoculum was spot inoculated on the surface of brain heart infusion agar with increasing concentrations of gentamicin and streptomycin antibiotics (HiMedia, Mumbai, India). The plates were incubated at $37^{\circ} \mathrm{C}$ for $24 \mathrm{hrs}$ and inspected for more than one colony forming units in the spotted area. Enterococcus faecalis ATCC 29212 was used as a negative control strain.

2.3. Molecular Analysis of Aminoglycoside Modifying Genes by PCR. The primers for AME genes such as aac $\left(6^{\prime}\right)-I e-$ $\operatorname{aph}\left(2^{\prime \prime}\right)-I a ; \operatorname{aph}\left(2^{\prime \prime}\right)-I b ; \operatorname{aph}\left(2^{\prime \prime}\right)-I c ; a p h\left(2^{\prime \prime}\right)-I d$ and $a p h\left(3^{\prime}\right)-$ IIIa included in this study were previously described [5].

PCR was carried out with reaction tube containing $1 \mu \mathrm{L}$ template DNA prepared from boiling lysis of bacterial suspension added to a $50 \mu \mathrm{L}$ reaction mixture containing $25 \mathrm{mM}$ Tris/ $\mathrm{HCl}, 50 \mathrm{mM} \mathrm{KCl}, 1.5 \mathrm{mM} \mathrm{MgCl}_{2}, 0.2 \mathrm{Mm}$ of each dNTP (Bangalore Genei, India), and 1.5 U Taq polymerase (Bangalore Genei, India). First reaction with a pair of $25 \mathrm{pmol}$ each of primers for $a a c\left(6^{\prime}\right)-I e-a p h\left(2^{\prime \prime}\right)-I a$ and $a p h\left(3^{\prime}\right)-I I I a$ (Sigma Aldrich, USA) and second reaction with $a p h\left(2^{\prime \prime}\right)-I b$, $\operatorname{aph}\left(2^{\prime \prime}\right)-I c, \operatorname{aph}\left(2^{\prime \prime}\right)$-Id primer sets separately.

Amplification was performed with PCR system (Eppendorf, Germany) and the cycling programs consisted of an initial denaturation $\left(95^{\circ} \mathrm{C}, 5 \mathrm{~min}\right)$ followed by 32 cycles each of denaturation $\left(95^{\circ} \mathrm{C}, 1 \mathrm{~min}\right)$, annealing $\left(58^{\circ} \mathrm{C}, 1 \mathrm{~min}\right)$ and extension $\left(72^{\circ} \mathrm{C}, 1 \mathrm{~min}\right)$, with a final extension of $\left(72^{\circ} \mathrm{C}\right.$, $5 \mathrm{~min})$. Each amplification product was resolved by electrophoresis with a 100-base pair molecular weight marker
(Real Biotech Corporation, Taiwan) in a 1.2\% agarose-Trisborate-EDTA gel stained with ethidium bromide $(0.5 \mu \mathrm{g} / \mathrm{mL})$ and visualized under gel documentation system (BioRad, USA). Table 1 shows the product size of all the genes analyzed.

\section{Results and Discussion}

3.1. Identification of Enterococcus Species. Since early 1970s, Enterococci were considered as nosocomial pathogens. The incidences of high level GM/SM resistance have been disseminated in many Enterococcus species. Since then, the high level aminoglycoside resistance has become a serious problem in most of the health care settings; identification of clinical isolates of enterococci up to species level is essential for an appropriate management of the infection. The predominant species observed in our study was E. faecalis $86 / 178(48.3 \%)$ as observed in previous studies [6] in our region. Other than $E$. faecium which was $80 / 178$ (44.9\%), we have also obtained $E$. avium (2\%), E. hirae (1.6\%), E. durans (0.6\%), E. gallinarum, and E. dispar (1\%). The species distribution and specimen source of isolates were listed in Table 2.

3.2. High Level Aminoglycoside Resistance in Enterococcal Isolates. Aminoglycoside antibiotics are considered efficient in treating serious infections caused by both gram positive and gram negative organisms. Due to acquisition of extrinsic resistance to high level aminoglycoside antibiotics in enterococci, these strains gain importance in clinical settings. A total of 178 enterococcal isolates were screened by MIC method, 76/178 (42.7\%) were HLGR $(\mathrm{MIC} \geq 512 \mu \mathrm{g} / \mathrm{mL})$ for gentamicin and 53/178 (29.8\%) were HLSR (MIC $\geq$ $2048 \mu \mathrm{g} / \mathrm{mL}$ ) for streptomycin (Table 3). Although the clinical use of streptomycin for enterococci has long been restricted due to intrinsic low level resistance (LLR), the present study revealed HLSR strains.

A total of 129/178 (72.47\%) high level aminoglycoside resistant enterococci (HLGR and HLSR) were observed among our study isolates.

Recent studies also indicated HLGR to be more common in all species of enterococci than HLSR. Similarly, we had observed HLGR to be more predominant than HLSR in our study isolates. One E. avium, E. hirae, E. durans, and E. gallinarum isolates were exhibiting MIC of $\geq 512 \mu \mathrm{g} / \mathrm{mL}$ for gentamicin and $\geq 2048 \mu \mathrm{g} / \mathrm{mL}$ for streptomycin antibiotics. The reports on resistance carried by species other than $E$. faecalis and E. faecium were observed from late 1990s [8]. A surveillance study that analyzed 20 European countries had 
TABLE 2: Distribution of Enterococcus species from various clinical specimens.

\begin{tabular}{|c|c|c|c|c|c|c|c|c|}
\hline \multirow{2}{*}{ Source of the isolates } & \multicolumn{7}{|c|}{ Distribution of Enterococcus spp. $(n=178)$} & \multirow{2}{*}{ Tota } \\
\hline & E. faecalis & E. faecium & E. durans & E. avium & E. hirae & E. dispar & E. gallinarum & \\
\hline Urine & 62 & 38 & - & 2 & 3 & 2 & - & 107 \\
\hline $\mathrm{DFU}^{\dagger}$ & 9 & 2 & 1 & 1 & - & - & - & 13 \\
\hline Blood & 7 & 35 & - & - & - & - & 2 & 44 \\
\hline Pus & 5 & 3 & - & 1 & - & - & - & 9 \\
\hline CSF & - & 1 & - & - & - & - & - & 1 \\
\hline Vaginal/semen swab & 3 & 1 & - & - & - & - & - & 4 \\
\hline Total & 86 & 80 & 1 & 4 & 3 & 2 & 2 & 178 \\
\hline
\end{tabular}

TABLE 3: Results of minimum inhibitory concentration of enterococcal isolates to gentamicin and streptomycin $(n=178)$.

\begin{tabular}{lcc}
\hline MIC $(\mu \mathrm{g} / \mathrm{mL})$ & $\begin{array}{c}\text { Gentamicin } \\
(n=178)\end{array}$ & $\begin{array}{c}\text { Streptomycin } \\
(n=178)\end{array}$ \\
\hline 0.50 & 0 & 0 \\
1 & 0 & 0 \\
2 & 1 & 1 \\
4 & 6 & 0 \\
8 & 8 & 0 \\
16 & 44 & 0 \\
32 & 15 & 0 \\
64 & 5 & 12 \\
128 & 19 & 85 \\
256 & 4 & 11 \\
$>512$ & 76 & 2 \\
1024 & $\mathrm{ND}^{\dagger}$ & 14 \\
$>2048$ & $\mathrm{ND}^{\dagger}$ & 53 \\
\hline
\end{tabular}

${ }^{\dagger} \mathrm{ND}$ : not done; HLGR > $500 \mu \mathrm{g} / \mathrm{mL} ; \mathrm{HLSR}>2000 \mu \mathrm{g} / \mathrm{mL}$ [7].

reported $32 \%$ and $22 \%$ HLGR and $41 \%$ and $49 \%$ HLSR among gentamicin resistant E. faecalis and E. faecium, respectively [9]. A very recent study conducted in Iran [10] had reported around $60.45 \%$ HLGR strains in their region. This is higher than our present report. They were suggesting cotransfer of these resistance genes along with VRE for the higher percentage of HLGR in their study. However, studies on AME gene profile were not done frequently in our region.

3.3. PCR Identification of HLAR Genes in Enterococci. All 178 enterococcal isolates were analyzed for the presence of aminoglycoside modifying enzyme coding genes (Figure 1).

High level gentamicin resistance is primarily due to the presence of bifunctional enzyme $a a c\left(6^{\prime}\right)-I e-a p h\left(2^{\prime \prime}\right)$-Ia which also confers high level resistance to amikacin, tobramycin, kanamycin, netilmicin, and dibekacin except streptomycin [11]. $a p h\left(2^{\prime \prime}\right)-I b$ was first detected from E. faecium and $E$. coli and confers high level resistance to gentamicin, tobramycin, amikacin, kanamycin, netilmicin, and dibekacin but not to amikacin. $a p h\left(2^{\prime \prime}\right)$-Ic confers HLR to gentamicin, tobramycin, and kanamycin while the strains carrying them can be treated with amikacin, netilmicin, and streptomycin

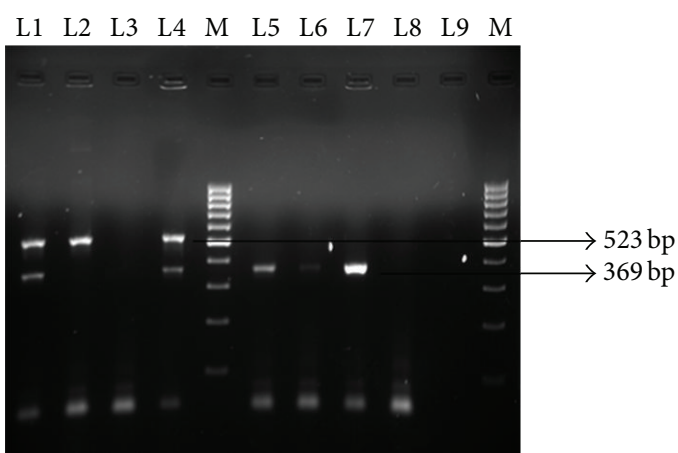

FIGURE 1: Amplified products of AME genes generated by multiplex PCR. L1, L2, L4-aph(3')-IIIa positive (523 bp); L1, L4, L5, L6, L7 $\operatorname{aac}\left(6^{\prime}\right)$-Ie-aph $\left(2^{\prime \prime}\right)$-Ia positive (369 bp); M-marker (100 bp DNA ladder).

in combination with cell wall inhibitors. Earlier this gene was shown to be present in E. gallinarum; but it had also been reported in isolates obtained from farm animals and in $E$. faecalis and E. faecium [12]. aph( $\left.2^{\prime \prime}\right)-I d$ was reported in E. casseliflavus and has similar mechanism to that of aph $\left(2^{\prime \prime}\right)$ $\mathrm{Ib}[13]$.

$\operatorname{aac}\left(6^{\prime}\right)$-Ie-aph $\left(2^{\prime \prime}\right)$-Ia gene was found in $38.2 \%$ of enterococcal isolates in our study. But, out of 76 strains of HLGR identified by MIC method, only 52 strains (68.4\%) carried $\operatorname{aac}\left(6^{\prime}\right)$-Ie-aph $\left(2^{\prime \prime}\right)$-Ia gene. However, 24/76 (31.57\%) isolates that were high level gentamicin resistant and 12/53 (22.64\%) isolates that were high level streptomycin resistant did not carry any of the genes tested. In a previous study [14], all the high level gentamicin resistant E. faecalis and E. faecium isolates were found to carry $a a c\left(6^{\prime}\right)$-Ie-aph( $\left.2^{\prime \prime}\right)$-Ia gene.

Newer aminoglycoside resistance genes such as aph $\left(2^{\prime \prime}\right)$ $I b, a p h\left(2^{\prime \prime}\right)-I c$, and $a p h\left(2^{\prime \prime}\right)-I d$ also found to encode high level resistance to gentamicin $(>500 \mu \mathrm{g} / \mathrm{mL})$ were not detected among our study isolates.

Another most important gene tested in our study, aph $\left(3^{\prime}\right)$ IIIa (GenBank Accession number: KF550184) was detected among $40.4 \%(72 / 178)$ isolates of enterococci. Out of 53 high level streptomycin resistant isolates, 41 (77.4\%) carried aph $\left(3^{\prime}\right)$-IIIa gene.

$20.2 \%(39 / 178)$ of strains carried both $a a c\left(6^{\prime}\right)-I e-a p h\left(2^{\prime \prime}\right)$ Ia and aph( $\left.3^{\prime}\right)$-IIIa genes in our study. Out of $39(21.9 \%)$ 
TABLE 4: Results of high level aminoglycoside resistance and distribution of aminoglycoside modifying enzyme encoding genes among Enterococcus spp.

\begin{tabular}{|c|c|c|c|c|c|c|c|c|}
\hline \multirow{2}{*}{$\begin{array}{l}\text { HLARE } \\
\text { (MIC and detection of } \\
\text { genes by PCR) }\end{array}$} & \multicolumn{7}{|c|}{ Distribution of high level aminoglycoside resistance in Enterococcus spp. $(n=178)$} & \multirow[b]{2}{*}{ Total } \\
\hline & $\begin{array}{c}\text { E. faecalis } \\
(86)\end{array}$ & $\begin{array}{l}\text { E. faecium } \\
(80)\end{array}$ & $\begin{array}{c}\text { E. durans } \\
\text { (1) }\end{array}$ & $\begin{array}{l}\text { E. avium } \\
\text { (4) }\end{array}$ & $\begin{array}{l}\text { E. hirae } \\
\text { (3) }\end{array}$ & $\begin{array}{c}\text { E. dispar } \\
\text { (2) }\end{array}$ & $\begin{array}{c}\text { E. gallinarum } \\
\text { (2) }\end{array}$ & \\
\hline HLGR $^{*}$ & 32 & 39 & 1 & 1 & 1 & 1 & 1 & 76 \\
\hline HLSR $^{*}$ & 21 & 27 & 1 & 1 & 1 & 1 & 1 & 53 \\
\hline $\operatorname{aac}\left(6^{\prime}\right)-I e-a p h\left(2^{\prime \prime}\right)-I a$ & 34 & 30 & 1 & 1 & 1 & - & 1 & 68 \\
\hline$a p h\left(2^{\prime \prime}\right)-I b$ & - & - & - & - & - & - & - & - \\
\hline $\operatorname{aph}\left(2^{\prime \prime}\right)-I c$ & - & - & - & - & - & - & - & - \\
\hline $\operatorname{aph}\left(2^{\prime \prime}\right)-I d$ & - & - & - & - & - & - & - & - \\
\hline $\operatorname{aph}\left(3^{\prime}\right)-I I I a$ & 34 & 30 & 1 & 2 & 1 & 2 & 2 & 72 \\
\hline
\end{tabular}

${ }^{*}$ HLGR; HLSR; MIC screening.

HLAR isolates which were resistant to both gentamicin (MIC $>512 \mu \mathrm{g} / \mathrm{mL}$ ) and streptomycin (MIC > $2048 \mu \mathrm{g} / \mathrm{mL}$ ) by MIC, $19(48.7 \%)$ isolates carried both the genes, and the remaining $38.5 \%$ isolates had one of the genes either $\operatorname{aac}\left(6^{\prime}\right)-\operatorname{Ie}$ - $\operatorname{aph}\left(2^{\prime}\right)$ Ia or aph $\left(3^{\prime}\right)$-IIIa gene, while $12.8 \%$ isolates did not carry neither of the genes tested.

E. faecalis, the predominant isolate of our study was found to carry $a a c\left(6^{\prime}\right)-I e-a p h\left(2^{\prime \prime}\right)$-Ia gene in 34/86 (39.5\%) isolates and aph(3')-IIIa gene in 34/86 (39.5\%) isolates. Another predominant pathogenic species obtained among our study isolates was Enterococcus faecium. 30/80 (37.5\%) E. faecium isolates with an MIC range between $128 \mu \mathrm{g} / \mathrm{mL}$ and $512 \mu \mathrm{g} / \mathrm{mL}$ carried the bifunctional enzyme coding gene $\operatorname{aac}\left(6^{\prime}\right)-I e-\operatorname{aph}\left(2^{\prime \prime}\right)-I a$.

Each of the HLAR E. avium, E. hirae, and E. durans had both the genes while another E. avium strain carried $a p h\left(3^{\prime}\right)$ IIIa with streptomycin MIC of $1024 \mu \mathrm{g} / \mathrm{mL}$. One of the two E. gallinarum strains isolated was HLAR and it carried both aminoglycoside resistance genes $\operatorname{aac}\left(6^{\prime}\right)-I e$-aph $\left(2^{\prime \prime}\right)-I a$ and $a p h\left(3^{\prime}\right)$-IIIa, while the other strain carried $a p h\left(3^{\prime}\right)$-IIIa gene alone but with an MIC of $\geq 16 \mu \mathrm{g} / \mathrm{mL}$ for gentamicin and $>64 \mu \mathrm{g} / \mathrm{mL}$ for streptomycin. One of the two E. dispar isolates in our study was found to be HLGR + HLSR and carried aph $\left(3^{\prime}\right)$-IIIa gene (see Table 4).

\section{Conclusion}

In our study, we had observed enterococcal isolates with phenotypic resistance towards high level gentamicin and streptomycin antibiotics without presence of respective AME gene. This may be due to the expression of genes other than genes analyzed in this study. The coexistence of $\operatorname{aac}\left(6^{\prime}\right)-I e-$ $a p h\left(2^{\prime \prime}\right)$-Ia and $a p h\left(3^{\prime}\right)$-IIIa was observed in $20.2 \%$ of the isolates.

Though an array of AMEs are responsible for HLAR status among Enterococcus species, we have demonstrated $\operatorname{aac}\left(6^{\prime}\right)$-Ie-aph $\left(2^{\prime \prime}\right)$-I $a$ and $a p h\left(3^{\prime}\right)$-III $a$ genes more frequently occurring than other genes. This observation emphasizes the restricted gene distribution and transfer of resistant genes within a geographical region. Hence, surveillance studies should be conducted among Enterococcus isolates from different sources in any given geographical area to document the
AME gene profile. Our study is the first to report resistance gene analysis among the Enterococcus species in India.

\section{Conflict of Interests}

The authors declare that there is no conflict of interests regarding the publication of this paper.

\section{References}

[1] S. Shindae, G. V. Koppikar, and S. Oommen, "Characterization and antimicrobial susceptibility pattern of clinical isolates of enterococci at a tertiary care hospital in Mumbai, India," Annals of Tropical Medicine and Public Health, vol. 5, no. 2, pp. 85-88, 2012.

[2] N. Kobayashi, M. Mahbub Alam, Y. Nishimoto, S. Urasawa, N. Uehara, and N. Watanabe, "Distribution of aminoglycoside resistance genes in recent clinical isolates of Enterococcus faecalis, Enterococcus faecium and Enterococcus avium," Epidemiology and Infection, vol. 126, no. 2, pp. 197-204, 2001.

[3] W. Washington, S. Allen, W. Janda et al., Koneman's Color Atlas and Textbook of Diagnostic Microbiology, 6th edition, 2006.

[4] S. Dutka-Malen, S. Evers, and P. Courvalin, "Detection of glycopeptide resistance genotypes and identification to the species level of clinically relevant enterococci by PCR," Journal of Clinical Microbiology, vol. 33, no. 1, pp. 24-27, 1995.

[5] S. B. Vakulenko, S. M. Donabedian, A. M. Voskresenskiy, M. J. Zervos, S. A. Lerner, and J. W. Chow, "Multiplex PCR for detection of aminoglycoside resistance genes in enterococci," Antimicrobial Agents and Chemotherapy, vol. 47, no. 4, pp. 14231426, 2003.

[6] S. Sreeja, P. R. Sreenivasa Babu, and A. G. Prathab, “The prevalence and the characterization of the Enterococcus species from various clinical samples in a tertiary care hospital," Journal of Clinical and Diagnostic Research, vol. 6, no. 9, pp. 1486-1488, 2012.

[7] Clinical Laboratory Standards Institute, "Performance standards for antimicrobial susceptibility testing, twenty-first informational supplement. M02-A10 and M07-A8," CLSI Document M100-S21, Clinical and Laboratory Standards Institute, Wayne, $\mathrm{Pa}, \mathrm{USa}, 2011$.

[8] D. F. Sahm, S. Boonlayangoor, and J. E. Schulz, "Detection of high-level aminoglycoside resistance in enterococci other than 
Enterococcus faecalis," Journal of Clinical Microbiology, vol. 29, no. 11, pp. 2595-2598, 1991.

[9] F.-J. Schmitz, J. Verhoef, and A. C. Fluit, "Prevalence of aminoglycoside resistance in 20 European university hospitals participating in the European SENTRY Antimicrobial Surveillance Programme," European Journal of Clinical Microbiology and Infectious Diseases, vol. 18, no. 6, pp. 414-421, 1999.

[10] A. Hasani, Y. Sharifi, R. Ghotaslon et al., "Molecular screening of virulence genes in high level gentamicin resistant Enterococcus faecalis and Enterococcus faecium isolated from clinical specimens in northwest Iran," Indian Journal of Medical Microbiology, vol. 30, no. 2, pp. 175-181, 2012.

[11] J. W. Chow, "Aminoglycoside resistance in enterococci," Clinical Infectious Diseases, vol. 31, no. 2, pp. 586-589, 2000.

[12] S. M. Donabedian, L. A. Thal, E. Hershberger et al., "Molecular characterization of gentamicin-resistant Enterococci in the United States: evidence of spread from animals to humans through food," Journal of Clinical Microbiology, vol. 41, no. 3, pp. 1109-1113, 2003.

[13] S. B. Vakulenko and S. Mobashery, "Versatility of aminoglycosides and prospects for their future," Clinical Microbiology Reviews, vol. 16, no. 3, pp. 430-450, 2003.

[14] R. Zarrilli, M.-F. Tripodi, A. Di Popolo et al., "Molecular epidemiology of high-level aminoglycoside-resistant enterococci isolated from patients in a university hospital in southern Italy," Journal of Antimicrobial Chemotherapy, vol. 56, no. 5, pp. 827835, 2005. 


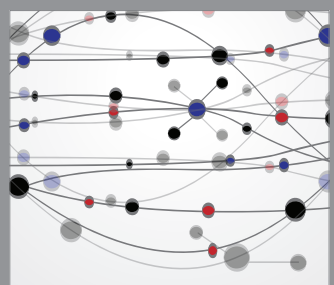

The Scientific World Journal
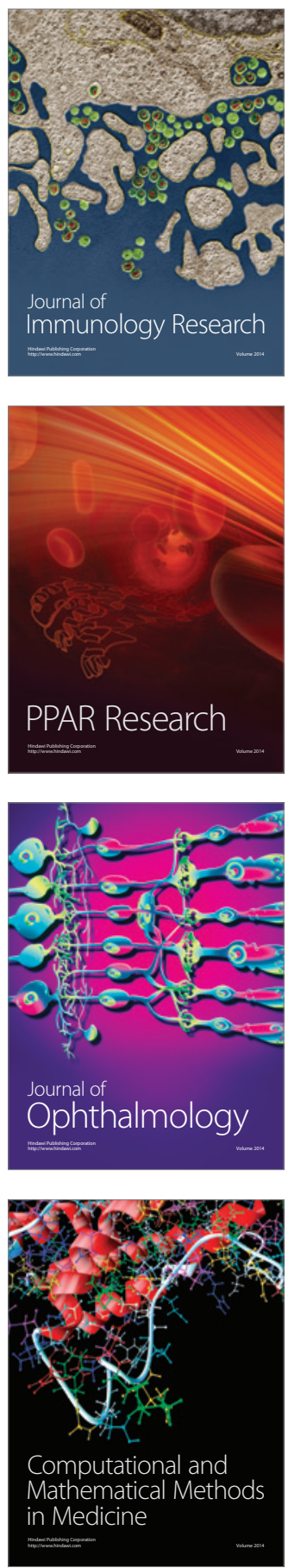

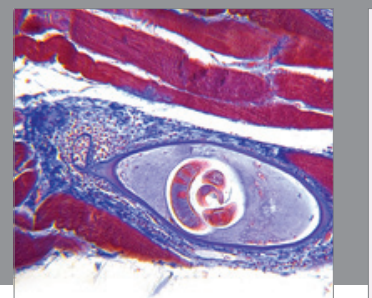

Gastroenterology

Research and Practice
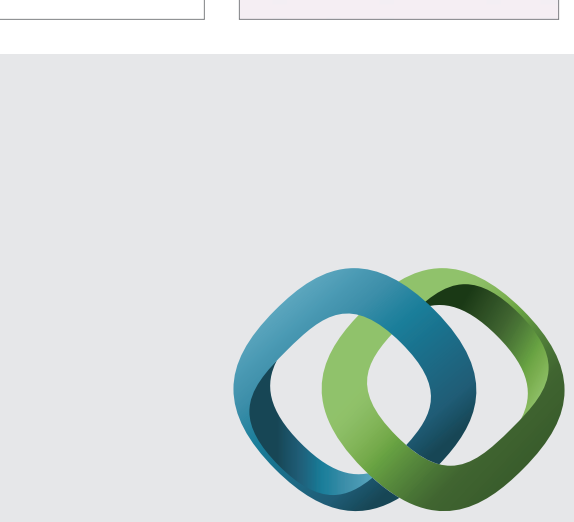

\section{Hindawi}

Submit your manuscripts at

http://www.hindawi.com
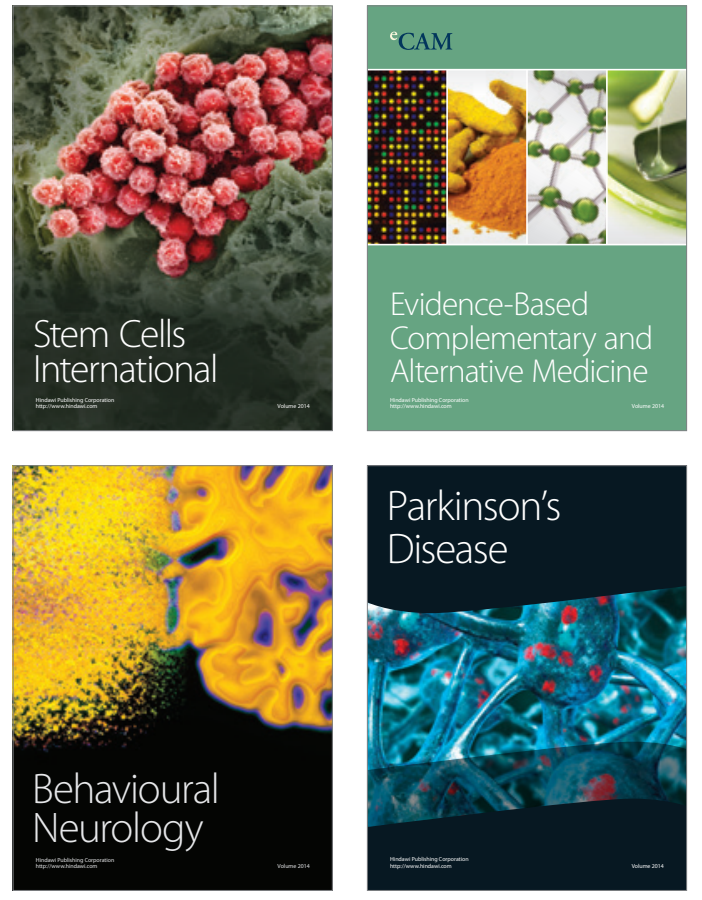
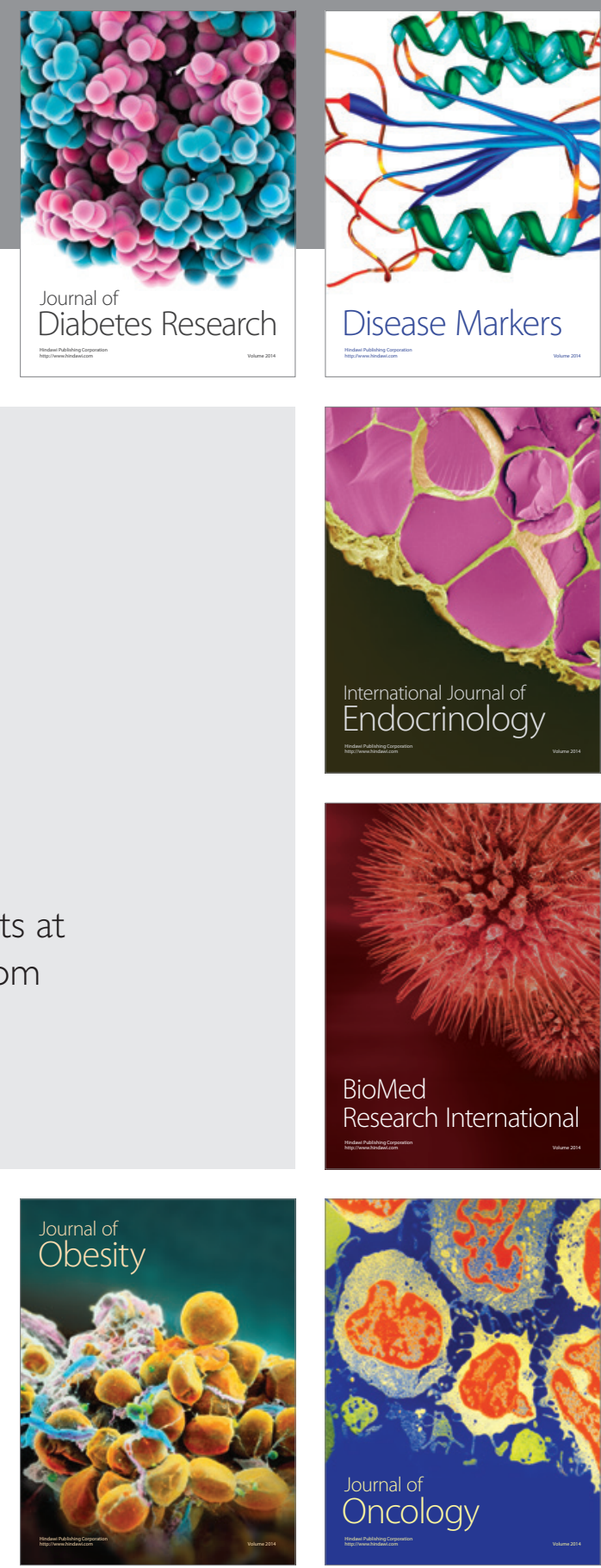

Disease Markers
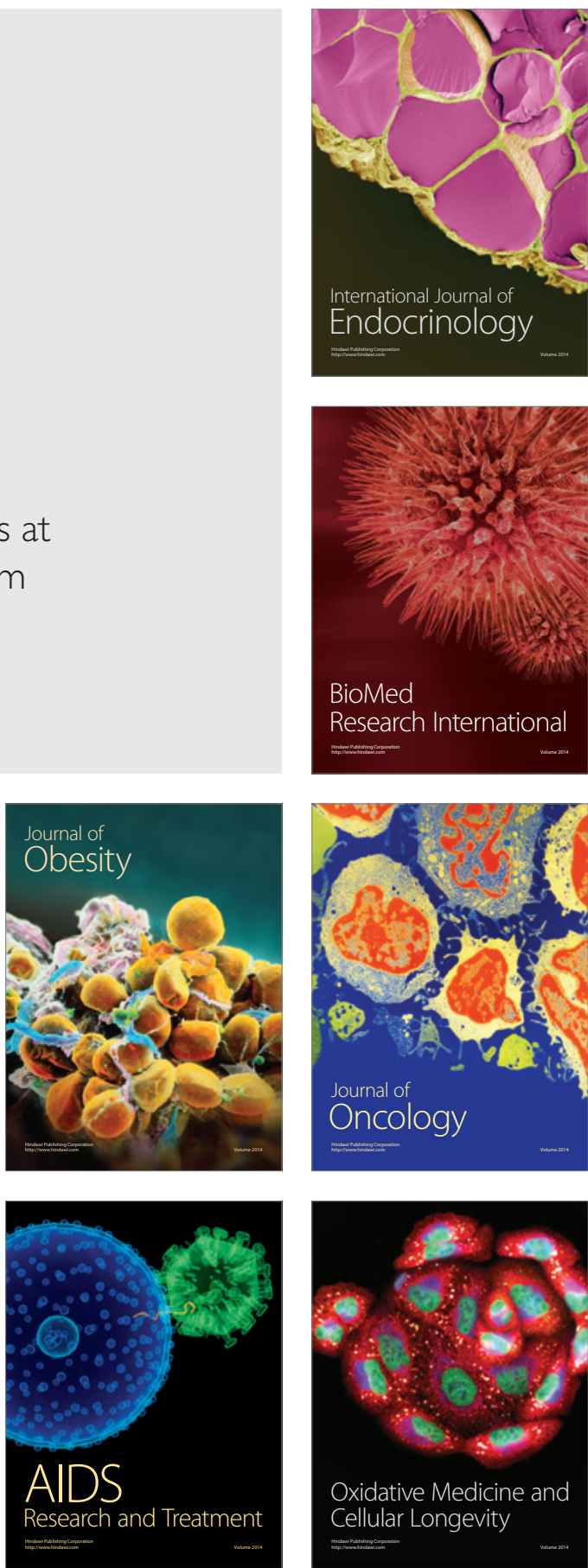